\title{
Penambahbaikan Sumber Jabatan Kecemasan menggunakan Kaedah Simulasi dan Analisis Pengumpulan Data
}

(Resources Improvement in Emergency Department using Simulation and Data Envelopment Analysis)

\author{
WAN MALISSA WAN MOHD AMINUDDIN, WAN ROSMANIRA ISMAIL* \& HUSYAIRI HARUNARASHID
}

\begin{abstract}
ABSTRAK
Jabatan Kecemasan Pusat Perubatan Universiti Kebangsaan Malaysia (PPUKM) menerima kedatangan pesakit yang ramai pada setiap hari menyebabkan jabatan ini kerap berdepan dengan masalah kesesakan. Justeru, objektif kajian ini adalah mengenal pasti model pengoptimuman terbaik untuk menambahbaik sumber bagi meningkatkan tahap kecekapan Jabatan Kecemasan PPUKM dan menyelesaikan masalah kesesakan jabatan. Kaedah simulasi digunakan bagi membina model jabatan kecemasan dengan pemboleh ubah yang digunakan dalam pemodelan simulasi ini adalah dikhususkan berdasarkan zon atau ruang rawatan. Alternatif penambahbaikan yang dicadangkan ini mengandungi konfigurasi bilangan sumber jabatan yang baru. Enam model gabungan yang digunakan terdiri daripada Model CCR dan Set Rujukan, Model BCC dan Set Rujukan, Model CCR dan Kecekapan-Super, Model BCC dan Kecekapan-Super, Model Bi-Objektif MCDEACCR dan Kecekapan Silang dan Model Bi-Objektif MCDEA-BCC dan Kecekapan Silang. Model Bi-Objektif MCDEA-BCC merupakan lanjutan kepada Model Bi-Objektif MCDEA-CCR daripada kajian terdahulu. Keputusan kajian menunjukkan Model Bi-Objektif MCDEA-BCC yang dibina telah memberikan bilangan alternatif penambahbaikan cekap yang paling kecil berbanding model-model gabungan lain. Melalui model gabungan ini juga satu alternatif penambahbaikan yang optimum yang telah dicadangkan dapat mengurangkan masa menunggu pesakit di Zon Hijau sebanyak $51 \%$ manakala peratusan penggunaan tenaga kerja sumber berjaya ditambahbaik agar lebih munasabah. Alternatif ini memerlukan susun atur kembali kedudukan sumber tanpa melakukan perubahan yang besar ke atas sistem asal.
\end{abstract}

Kata kunci: Analisis Pengumpulan Data; jabatan kecemasan; kesesakan; pengoptimuman sumber; simulasi

ABSTRACT

The Emergency Department of Universiti Kebangsaan Medical Centre (PPUKM) receives a high number of patients daily resulted in numerous problems particularly overcrowding. Therefore, this study is designed to identify the best optimization model that improve resources in order to improve the efficiency level of the PPUKM Emergency Department and solve the overcrowding problem. Simulation technique is used to build a simulation model of the emergency department where the variables used in the model are specified by triage zones or treatment areas. The proposed alternative improvements contains a new configuration of department resources. Six combined models used are the CCR Model and Reference Set, BCC Model and Reference Set, CCR Model and Super-Efficiency, BCC Model and Super-Efficiency, Bi-Objective MCDEA-CCR Model and Cross-Efficiency and Bi-Objective MCDEA-BCC Model and Cross Efficiency. Bi-Objective MCDEA-BCC Model is a continuation of Bi-Objective MCDEA-CCR Model from previous studies. The results showed that the Bi-Objective MCDEA-BCC Model has derived the least number of efficient alternative improvements compared to other combined models. It also suggested an optimum alternative that can reduce the patient waiting time in the Green Zone by $51 \%$ while the percentage of resource utilisation has been improved to be more reasonable. This alternative needs redesigning the department's resources without making major changes to the original system.

Keywords: Data Envelopment Analysis; emergency department; overcrowding; resource optimisation; simulation

\section{PENGENALAN}

Dewasa ini, hampir kebanyakan jabatan kecemasan di hospital-hospital di bawah pentadbiran kerajaan menerima bilangan pesakit yang ramai pada setiap hari (Subramaniam 2016). Kepadatan pesakit di jabatan ini telah memberi tekanan kepada pihak pentadbiran jabatan untuk terus menambah baik kecekapan sistem penyampaian rawatan akibat kekangan kewangan, bilangan sumber yang terhad dan kos penyediaan serta penyelenggaraan peralatan perubatan yang mahal (Redeker et al. 2017). Hal ini telah menjadi punca kepada kerap berlakunya masalah utama jabatan kecemasan iaitu kesesakan (Somma et al. 2015; Yarmohammadian et al. 2017).

Kesesakan di jabatan kecemasan dapat ditakrifkan sebagai ketidakupayaan jabatan kecemasan dalam memberikan perkhidmatan perubatan kecemasan yang berkualiti dalam tempoh masa yang munasabah demi memenuhi permintaan para pesakit yang tinggi (Azlan et al. 2013). Kesesakan yang kerap berlaku di jabatan kecemasan banyak memberikan kesan negatif yang dapat 
mencerminkan bahawa imej sistem perkhidmatan di jabatan berkenaan adalah tidak cekap. Seandainya perkara ini tidak dibendung pada peringkat awal, pelbagai kesan buruk boleh berlaku seperti kelewatan menerima rawatan, pesakit menunggu lama khususnya bagi kes-kes bukan kritikal, ketidakpuasan hati terhadap khidmat layanan rawatan yang diberi oleh pihak jabatan, peratusan beban kerja yang tinggi dalam kalangan sumber jabatan dan peningkatan kadar kematian (Cowan \& Trzeciak 2005; Di et al. 2015).

Jabatan Kecemasan Pusat Perubatan Universiti Kebangsaan Malaysia (PPUKM) merupakan salah satu komponen penting dalam menyediakan khidmat rawatan kesihatan kepada para pesakit yang hadir ke hospital ini. Kedudukannya yang strategik telah menjadikan jabatan ini sentiasa sibuk mengurus pesakit yang ramai. Selain itu, kepakaran lengkap yang disediakan turut menarik minat ramai pesakit untuk mendapatkan rawatan di sini. Bertanggungjawab mengurus bilangan pesakit yang ramai pada setiap hari, menjadikan jabatan ini turut berulang kali berdepan dengan masalah kesesakan. Berdasarkan laporan kes oleh Azlan et al. (2013), jabatan ini telah mengalami kesesakan yang paling buruk yang pernah dialami oleh mereka. Jabatan tersebut terpaksa menutup Zon Hijau dan beroperasi dengan hanya menerima pesakit kritikal dan separa kritikal sahaja. Bilik rawatan di Zon Hijau telah diubah untuk menempatkan pesakit Zon Kuning. Bagi menampung kekurangan katil pula, katil lipat kanvas telah digunakan manakala kakitangan Zon Hijau diarahkan membantu di zon-zon lain bagi menampung kekurangan staf.

Menyedari hakikat ini, amatlah penting masalah kesesakan di Jabatan Kecemasan PPUKM diberi perhatian yang tinggi. Langkah-langkah penyelesaian perlu dipergiatkan bagi memulihkan kecekapan sistem operasi Jabatan Kecemasan, PPUKM agar kesesakan tidak berlaku secara kerap dan terus membelenggu pihak pengurusan hospital serta masyarakat umum. Justeru, langkah yang terbaik dalam memperbaiki masalah kesesakan di jabatan kecemasan adalah dengan menaik taraf kecekapan jabatan melalui pengoptimuman sumber (Jeenanunta et al. 2013). Penambahbaikan dalam pengoptimuman sumber yang dilakukan dalam kajian ini dapat memastikan jabatan tersebut mempunyai sumber yang mencukupi dan dimanfaatkan penggunaan secara optimum. Hal ini dapat mengelakkan sumbernya terbeban dengan bebanan kerja yang tinggi atau berlakunya lebihan sumber pada sesuatu bahagian. Oleh itu, kerja harian dapat dijalankan dengan lancar serta masyarakat akan berpuas hati terhadap khidmat rawatan yang disediakan kepada mereka.

Objektif utama kajian yang dijalankan adalah untuk mengenal pasti model pengoptimuman terbaik bagi meningkatkan tahap kecekapan sistem jabatan dan menyelesaikan masalah kesesakan jabatan. Kajian ini mencadangkan alternatif penambahbaikan yang dikenali sebagai Unit Pembuat Keputusan (DMU) bagi menyelesaikan isu kesesakan. Alternatif penambahbaikan yang disarankan mengandungi konfigurasi sumber jabatan yang baru. Bagi mendapatkan bilangan sumber yang paling optimum, simulasi dan Analisis Pengumpulan Data (DEA) digunakan.

Simulasi merupakan satu kaedah yang sering digunakan oleh para pengkaji bagi menyelesaikan masalah kesesakan jabatan kecemasan (Paul et al. 2010). Brailsford (2007) menyatakan bahawa peningkatan penerimaan penggunaan simulasi oleh sebilangan penyelidik dalam menangani masalah dalam bidang kesihatan adalah didorong oleh tiga aspek penting. Pertama, sistem kesihatan memerlukan sebuah pendekatan stokastik dalam menangani isu ketidaktentuan dan kepelbagaian senario perubatan yang berlaku dalam sistem berkenaan. Kedua, sistem kesihatan adalah merupakan suatu sistem kompleks yang memerlukan penggunaan pendekatan pemodelan yang dapat menangani isu kekompleksan sistem dan kekompleksan masalah dalam sistem dengan sangat efektif. Ketiga, peranan penting yang dimainkan oleh manusia dalam sistem kesihatan memerlukan pendekatan yang membolehkan interaksi dan komunikasi antara pembina model dan pengguna model. Justeru, ketiga-tiga aspek ini merupakan kelebihan yang ada dalam simulasi dan telah menjadi pendorong utama kepada penggunaannya secara meluas dalam bidang kajian kesihatan.

Namun demikian, simulasi dilihat tidak dapat digunakan secara tunggal sebagai satu kaedah pengoptimuman (Jun et al. 2013; Zeinali et al. 2015). Hal ini kerana simulasi hanya mampu memberikan analisis keputusan yang khusus akan setiap apa-jika senario/alternatif penambahbaikan yang dilakukan tanpa menyediakan satu keputusan yang paling optimum untuk diaplikasi ke dalam sistem (Uriarte et al. 2015). Meskipun satu alternatif penambahbaikan optimum dapat dicadangkan, ini akan memerlukan peruntukan sejumlah masa yang besar khususnya apabila melibatkan bilangan alternatif yang banyak kerana proses pemilihan ini perlu dilakukan secara manual dengan cara membandingkan setiap dapatan simulasi alternatif yang terlibat.

Menyedari hakikat ini, kebanyakan pengkaji menggabungkan kaedah simulasi dengan kaedah pengoptimuman lain seperti pengaturcaraan linear (Centeno et al. 2003), analisis keputusan kriteria pelbagai (Eskandari et al. 2011) dan analisis pengumpulan data (DEA) (Al-Refaie et al. 2014; Azadeh et al. 2013; Carmen et al. 2015; Gharahighehi et al. 2016; Weng et al. 2011) bagi mendapatkan satu solusi optimum untuk menambahbaik sistem kajian mereka. Antara kaedah pengoptimuman tersebut DEA dan simulasi dilihat sering digabungkan bagi meningkatkan tahap kecekapan jabatan kecemasan.

\section{JABATAN KECEMASAN PPUKM}

Di Jabatan Kecemasan PPUKM, para pesakit ini akan diasingkan ke ruang rawatan berbeza yang terbahagi kepada tiga zon warna iaitu Merah, Kuning dan Hijau. Zon Merah berfungsi bagi mengurus kes yang amat serius, kritikal dan mengancam nyawa yang memerlukan rawatan segera. Zon Kuning pula mengendali kes separa kritikal 
yang mengancam nyawa tapi tidak memerlukan perawatan segera manakala Zon Hijau untuk merawat kes kecemasan biasa yang bukan kritikal dan tidak mengancam nyawa (Medical Development Division 2012).

Proses rawatan setiap pesakit dilakukan di zon rawatan berasingan dan dikendalikan oleh pasukan rawatan yang dikhaskan bertugas di setiap zon berkenaan. Pasukan Zon Merah terdiri daripada seorang doktor dan lima orang jururawat pada setiap syif. Terdapat lima buah katil disediakan untuk menempatkan pesakit kritikal di zon ini pada satu-satu masa. Pasukan Zon Kuning terdiri daripada dua orang doktor. Bilangan jururawat adalah enam orang dalam syif pagi dan syif petang manakala pada syif malam hanya terdapat empat orang jururawat sahaja yang bertugas. Terdapat dua belas katil di zon ini bagi menempatkan para pesakit pada satu-satu masa. Pasukan Zon Hijau pula terdiri daripada beberapa orang doktor dan seorang jururawat. Terdapat enam bilik rawatan yang disediakan, namun bilik ini hanya berfungsi bergantung kepada bilangan doktor yang bertugas.

Dalam sistem operasi Jabatan kecemasan PPUKM ini, kesemua kakitangannya bekerja mengikut syif kerja yang terbahagi kepada tiga jenis iaitu syif pagi (7.00 pagi - 2.00 petang), syif petang (2.00 petang - 9.00 malam) dan syif malam (9.00 malam - 7.00 pagi (hari berikutnya)). Walau bagaimanapun, terdapat perbezaan masa bekerja bagi doktor di Zon Hijau. Jadual kerja Doktor Zon Hijau adalah seperti berikut; seorang doktor dijadualkan bekerja di Zon Hijau pada jam 7.00 pagi-10.00 pagi, tiga orang doktor dijadualkan pada jam 10.00 pagi - 5.00 petang, tiga orang doktor dijadualkan pada jam 5.00 petang - 11.00 malam dan dua orang doktor dijadualkan pada jam 11.00 malam - 7.00 pagi keesokan harinya.

\section{KAEDAH KAJIAN}

Pengoptimuman sumber iaitu melibatkan sumber manusia iaitu doktor dan jururawat, manakala sumber bukan manusia iaitu katil di Jabatan Kecemasan telah dilakukan. Pengoptimuman ini dilakukan bagi memastikan bilangan sumber yang ditempatkan dalam jabatan kecemasan adalah mencukupi dan dimanfaatkan secara optimum. Bagi merealisasikan objektif ini, sebuah kerangka kerja telah dibentuk (Rajah 1). Kerangka kerja ini terbahagi kepada 3 fasa perlaksanaan iaitu fasa 1 membina model simulasi, fasa 2 mengenal pasti alternatif penambahbaikan atau DMU yang cekap menggunakan kaedah Analisis Pengumpulan Data (DEA) dan fasa 3 mengenal pasti alternatif penambahbaikan paling cekap menggunakan gabungan model-model DEA dan kaedah-kaedah meningkatkan kuasa mendiskriminasi model-model DEA.

\section{SIMULASI}

Setiap penyelidikan yang melibatkan pembinaan model simulasi akan melalui langkah-langkah pembinaan model yang sama. Hal ini bagi memastikan model yang dibina

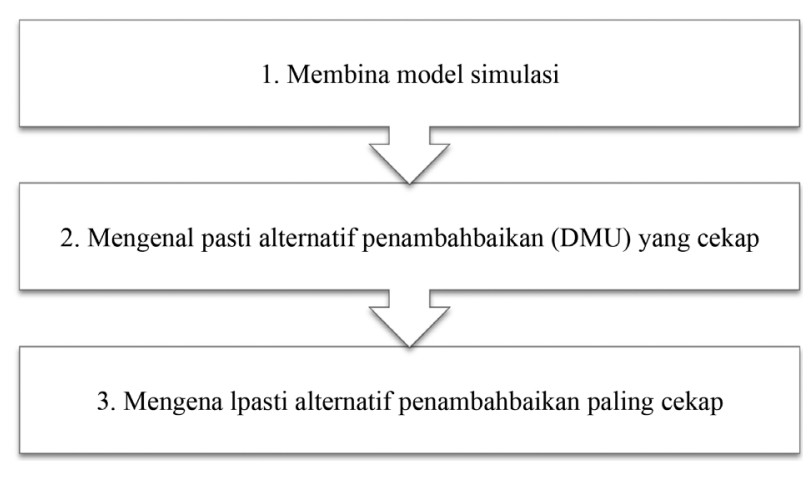

RAJAH 1. Kerangka kerja kajian

ini benar-benar dapat diguna pakai bagi menjalankan sebarang uji kaji penyelidikan dan mencapai objektif yang telah ditetapkan dengan cemerlang. Secara amnya langkah-langkah dalam melaksanakan kajian simulasi seperti yang disarankan oleh beberapa pengkaji simulasi adalah: Analisis masalah dan pengumpulan maklumat; Pengumpulan data; Pembinaan model simulasi; Ujian pengtahkikan model; Ujian pengesahan model; Larian model dan analisis keputusan; serta dokumentasi keputusan dan cadangan penambahbaikan model (Kelton et al. 2010). Dalam kajian ini, langkah-langkah yang sama turut diaplikasikan bagi membina model simulasi jabatan kecemasan yang dikaji.

Pengtahkikan model ialah sebuah ujian yang dilakukan terhadap sesebuah model simulasi bagi memastikan model yang dibina ini berkelakuan atau berjalan seperti yang dirancangkan oleh pembuat model dan bebas daripada sebarang ralat (Carson 2002). Pengesahan model pula merupakan satu ujian yang dijalankan terhadap model simulasi untuk menentukan sama ada model dibina secukupnya mewakili sistem sebenar (Carson 2002). Pendekatan terbaik bagi melakukan ujian pengesahan ini adalah dengan membandingkan sebilangan keputusan yang dijana oleh model simulasi dengan data sebenar sistem. Apabila nilai kedua-dua set data yang dibandingkan ini rapat, maka model yang dibina ini adalah sahih dan boleh digunakan untuk menjalankan aktiviti kajian (Ruohonen et al. 2006). Perbandingan antara data sebenar dan keputusan simulasi diberikan dalam nilai peratusan ralat menggunakan formula peratusan ralat yang dinyatakan ini. Model simulasi itu dikatakan sah apabila nilai peratusan ralat yang dikira adalah kurang daripada 10\% (Tahar 2006).

$$
\begin{aligned}
& \text { Peratusan } \\
& \text { Ralat }
\end{aligned}=\frac{\mid \text { Output Simulasi }- \text { Data Sebenar } \mid}{\text { Data Sebenar }} \times 100 \%
$$

Dalam kajian ini, perbandingan dibuat dengan menggunakan data bancian yang diambil daripada rekod data jabatan kecemasan dengan keputusan (output) simulasi. Model simulasi ini ditetapkan lariannya kepada satu hari dengan bilangan 12 replikasi. Keputusan yang dikehendaki bagi menjalankan ujian ini diambil di akhir proses larian yang telah dibuat. 


\section{ANALISIS PENGUMPULAN DATA}

Analisis Pengumpulan Data (DEA) telah diperkenalkan oleh Charnes et al. sekitar tahun 1978. DEA ditakrifkan sebagai satu kaedah yang berasaskan pengaturcaraan linear yang digunakan untuk menilai prestasi atau mengukur tahap kecekapan relatif sesuatu entiti yang dikenali sebagai Unit Pembuat Keputusan (DMU), menggunakan input dan output yang ditetapkan. Antara contoh DMU adalah firma-firma perniagaan, agensi-agensi kerajaan dan pengurus-pengurus syarikat. Input dan output yang ditetapkan dalam model ini adalah merupakan ukuran prestasi yang digunakan bagi mengira skor kecekapan setiap DMU (Moashiri et al.2011). Nilai-nilai ini kemudiannya digunakan untuk mengira pemberat setiap input dan output yang digunakan untuk mengira kecekapan DMU (Cooper et al. 2007).

Dalam kajian ini, input yang telah ditetapkan adalah bilangan katil, bilangan doktor, bilangan jururawat, masa menunggu Zon Kuning, Zon Hijau dan rawatan kali ke-2 di Zon Hijau. Manakala peratusan penggunaan katil, peratusan penggunaan Doktor Zon Merah, Doktor Zon Kuning, Doktor Zon Hijau, Jururawat Zon Merah, Jururawat Zon Kuning dan bilangan pesakit selesai dirawat pula ditetapkan sebagai output.

Dalam kajian lepas, DEA telah digunakan untuk memilih satu alternatif penambahbaikan yang dapat mengoptimumkan bilangan sumber dan membaiki kekurangan jabatan kecemasan. Menerusi kaedah ini, setiap alternatif penambahbaikan dijadikan sebagai DMU yang mengandungi konfigurasi baru sumber jabatan kecemasan dan model-model DEA seperti Model DEA oleh Charnes, Cooper dan Rhodes atau dikenali oleh Model CCR (Charnes et al. 1978) dan Model DEA oleh Banker, Charnes dan Cooper atau dikenali dengan Model BCC (Banker et al. 1984) digunakan untuk mengukur nilai kecekapan setiap DMU relatif kepada kesemua DMU-DMU yang terlibat. Keputusan pengiraan kecekapan ini membolehkan DMU yang cekap dan DMU tidak cekap dapat dikenal pasti dengan jelas. Antara kajian lepas yang mengguna pakai DEA dalam melakukan pengoptimum sumber adalah AlRefaie et al. (2014), Azadeh et al. (2013), Carmen et al. (2015), Gharahighehi et al. (2016) dan Weng et al. (2011).

Walau bagaimanapun, sejak kedua-dua model klasik DEA iaitu model CCR dan model BCC diperkenalkan, dua kelemahan penting telah dikenal pasti wujud. Kelemahan tersebut adalah ketidakupayaan untuk mendiskriminasi dalam kalangan DMU cekap dan pengagihan pemberat input dan pemberat output yang tidak realistik ( $\mathrm{Li} \&$ Reeves 1999; Meza \& Lins 2002). Bagi menangani kelemahan ini pelbagai penambahbaikan telah dilakukan ke atas model berkenaan.

Terdapat kaedah meningkatkan kuasa mendiskriminasi model klasik DEA seperti Set Rujukan (Emrouznejad 2012), Kecekapan-Super (Andersen \& Petersen 1993) dan Kaedah Kecekapan Silang (Sexton 1986) telah dicadangkan dalam kesusasteraan DEA sebagai strategi untuk membantu menyelesaikan kekurangan dalam DEA ini. Meskipun begitu, masih terdapat kelemahan yang wujud dalam kaedah-kaedah yang dihasilkan ini (Ghasemi et al. 2014;
Meza \& Lins 2002) yang mungkin membawa kepada keputusan yang kurang tepat dan lemah dalam membuat keputusan.

Ghasemi et al. (2014) telah membangunkan model yang dikenali sebagai Bi-Objective Multi Criteria Data Envelopment Analysis-CCR (Bi-O MCDEA-CCR). Model ini merupakan penambahbaikan yang dilakukan ke atas Model Analisis Pengumpulan Data Kriteria Pelbagai (MCDEA) dan Model Pengaturcaraan Gol-Analisis Pengumpulan Data (GP DEA) sebagai satu alternatif untuk menyelesaikan kelemahan DEA (Bal \& Orkc 2010). Model ini telah berjaya menggabungkan ketiga-tiga objektif yang terdapat dalam Model MCDEA dengan menjadikannya sebagai satu objektif tunggal sahaja (Carrilloa \& Jorge 2015; Francisco et al. 2017). Kesan penghasilan satu model tunggal ini telah dapat memendekkan proses pengiraan dan mengurangkan berlakunya ralat semasa proses pengiraan nilai kecekapan dijalankan.

Selain itu, pengenalan kekangan baru dan penggunaan pemboleh ubah sisihan dalam kekangan model menjadikan model Bi-O MCDEA-CCR ini mempunyai kuasa mendiskriminasi yang lebih baik bagi mengukur kecekapan setiap alternatif dan menjadikan pembahagian nilai pemberat input dan output yang lebih releven berbanding Model MCDEA dan Model GP DEA (Lv et al. 2015). Hal ini menyumbang kepada pengurangan bilangan DMU yang diukur sebagai cekap. Kekuatan Model Bi-O MCDEA-CCR dalam menangani masalah yang wujud dalam model klasik DEA dan model DEA yang terdahulu telah menunjukkan bahawa model ini adalah lebih sesuai untuk digunakan. Hal ini turut dibuktikan oleh Francisco et al. (2017), yang telah mengaplikasi model ini bagi mengenal pasti ciri parameter yang paling sesuai untuk ditambah baik bagi meningkatkan tahap kecekapan kedua-dua mesin tekanan yang terdapat di sebuah kilang pembuatan kereta dan lori di Brazil.

Namun demikian, penggunaan model-model DEA ini akan berkemungkinan memberikan lebih daripada satu DMU yang cekap dan tidak dapat memberikan satu DMU paling cekap. Oleh yang demikian, kaedah gabungan digunakan bagi memilih DMU paling cekap. Model gabungan ini dilakukan dengan menggabungkan model DEA yang digunakan dengan Set Rujukan, KecekapanSuper dan Kecekapan Silang. Menerusi kaedah gabungan ini, DMU cekap akan disusun berdasarkan kedudukan nilai kecekapan yang baru dan DMU cekap yang berada di kedudukan tertinggi adalah dianggap sebagai yang paling cekap. Rajah 2 menunjukkan model-model gabungan yang digunakan.

Oleh kerana terdapat perbezaan antara DMU paling cekap disebabkan pelbagai model gabungan yang digunakan, perbandingan perlu dibuat untuk memilih DMU paling cekap dan terbaik (optimum) untuk mendapatkan hanya satu DMU sebagai rujukan. Elemen yang dibandingkan adalah melibatkan masa menunggu dan kadar penggunaan tenaga kerja sumber. Di samping itu, bilangan katil, bilangan doktor, bilangan jururawat dan peratusan penggunaan katil turut ditambah sebagai item 


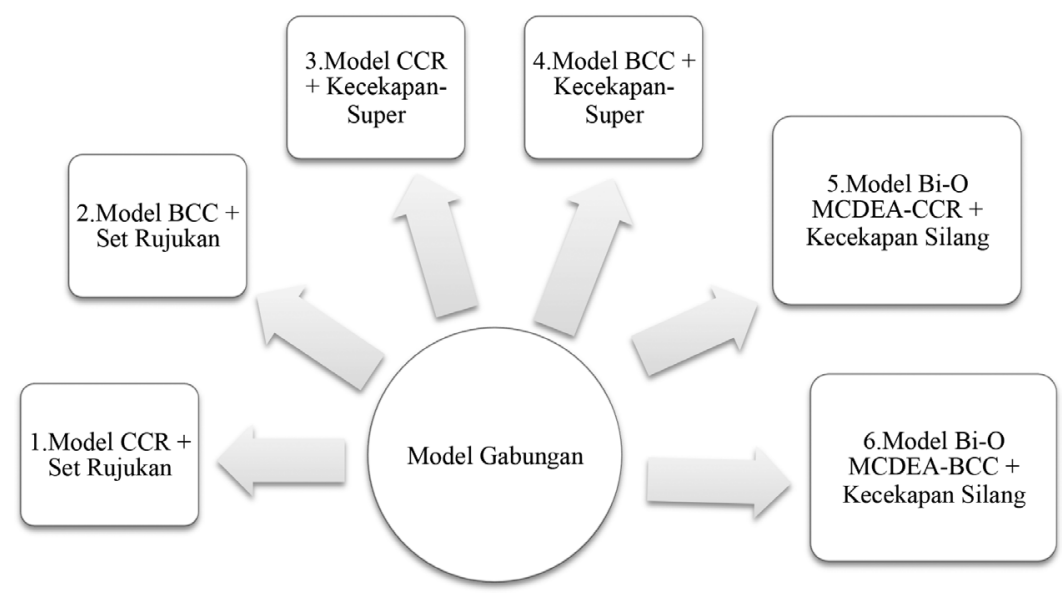

RAJAH 2. Model gabungan bagi mendapatkan alternatif penambahbaikan paling cekap

perbandingan dan seterusnya memilih DMU sebagai paling cekap dan terbaik yang mengandungi bilangan sumber yang optimum.

\section{KEPUTUSAN DAN PERBINCANGAN}

Terdapat tiga jenis data input yang diperlukan untuk membina Model Simulasi Jabatan Kecemasan PPUKM. Data input tersebut adalah taburan kebarangkalian kedatangan pesakit, taburan kebarangkalian tempoh masa perkhidmatan pada setiap aktiviti dan cabang peratusan kebarangkalian sesuatu aktiviti. Bilangan pesakit yang melakukan setiap aktiviti ini dicatat semasa proses pengumpulan data. Pengiraan peratusan bilangan pesakit kemudiannya dilakukan dan dijadikan sebagai data input bagi setiap aktiviti. Rajah 3 menunjukkan sebahagian daripada model simulasi yang dibina menggunakan Perisian Arena.

Selepas model simulasi berkenaan diperoleh, ujian pengesahan model dilakukan. Keputusan pengiraan ralat bagi ujian pengesahan model simulasi ditunjukkan dalam Jadual 1. Nilai peratusan ralat kesemua perbandingan ini adalah kurang daripada 10\%. Justeru, dapatlah disimpulkan bahawa Model Simulasi Jabatan Kecemasan PPUKM adalah sah dan keputusannya munasabah digunakan untuk menjalankan uji kaji bagi menambahbaik sistem jabatan.

Jadual 2 menunjukkan satu contoh untuk DMU1 yang mewakili konfigurasi bilangan sumber semasa yang terdapat dalam sistem jabatan kecemasan ini. DMU1 bermaksud terdapat seorang Doktor Zon Merah pada setiap syif kerja pagi (a), petang (b) dan malam (c). Bagi Doktor Zon Kuning pula, terdapat 2 orang doktor

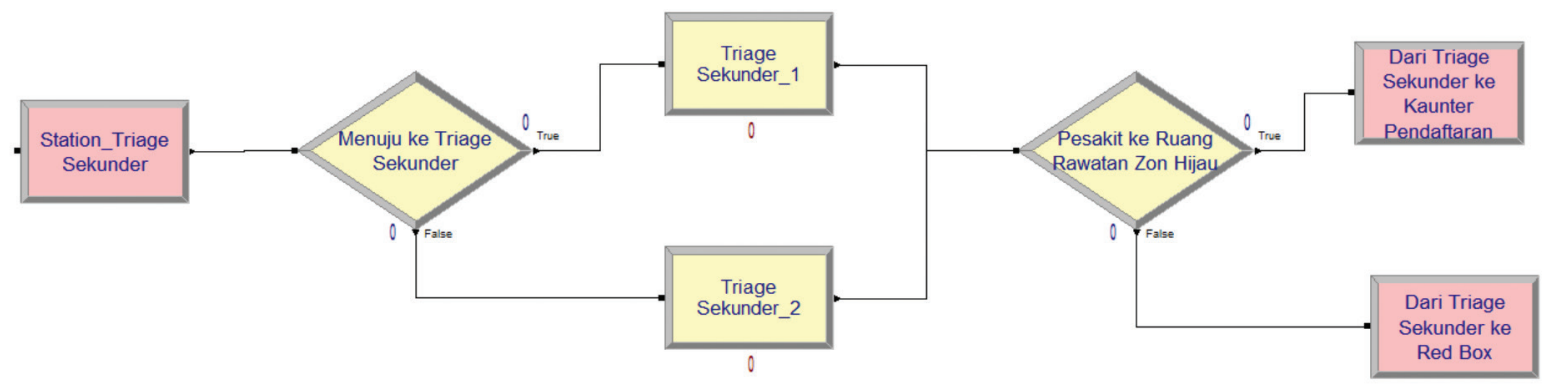

RAJAH 3. Model Arena sebahagian Jabatan Kecemasan PPUKM

JADUAL 1. Peratusan ralat model

\begin{tabular}{lccc}
\hline Item & Data sebenar & Keputusan simulasi & Ralat $(\%)$ \\
\hline Bilangan kedatangan pesakit & 200 & 195 & 2.5 \\
Bilangan pesakit ke Triage Primari & 200 & 195 & 2.5 \\
Bilangan pesakit ke Triage Sekunder & 130 & 135 & 3.8 \\
Bilangan pesakit ke RedBox & 64 & 67 & 4.6 \\
Bilangan pesakit ke Zon Merah & 7 & 7 & 0 \\
Bilangan pesakit ke Zon Kuning & 60 & 59 & 1.7 \\
Bilangan pesakit ke Zon Hijau & 130 & 126 & 3.1 \\
\hline
\end{tabular}


JADUAL 2. Contoh alternatif penambahbaikan/DMU

\begin{tabular}{ccccccc}
\hline DMU & $\begin{array}{c}\text { Doktor Zon } \\
\text { Merah }\end{array}$ & $\begin{array}{c}\text { Doktor Zon } \\
\text { Kuning }\end{array}$ & $\begin{array}{c}\text { Doktor Zon } \\
\text { Hijau }\end{array}$ & $\begin{array}{c}\text { Jururawat Zon } \\
\text { Merah }\end{array}$ & $\begin{array}{c}\text { Jururawat Zon } \\
\text { Kuning }\end{array}$ & Katil \\
\hline 1 & $\left(1^{\mathrm{a}}, 1^{\mathrm{b}}, 1^{\mathrm{c}}\right)$ & $(2,2,2)$ & $\mathrm{S} 1$ & $(5,5,5)$ & $(6,6,4)$ & 17 \\
\hline
\end{tabular}

bertugas pada setiap syif manakala Doktor Zon Hijau menggunakan Jadual Kerja Doktor Zon Hijau 1 (S1) iaitu seramai sembilan doktor (satu doktor pada syif 0700 1000 , tiga doktor pada syif 1000 - 1700, tiga doktor pada syif 1700 - 2300 dan dua doktor pada syif 2300 - 0700). Sementara itu, bilangan jururawat di Zon Merah dalam ketiga-tiga syif kerja adalah sama iaitu 5 orang. Di Zon Kuning, 6 orang jururawat bekerja pada syif kerja pagi dan petang manakala hanya 4 orang jururawat bekerja pada syif malam. Jumlah keseluruhan bilangan katil rawatan pula adalah sebanyak 17 buah. DMU2 hingga ke DMU144 pula merupakan konfigurasi baru sumber yang dicadangkan bagi menyelesaikan masalah jabatan ini dan penerangannya adalah sama seperti yang dinyatakan dalam DMU1.

Rumusan keputusan kajian menggunakan keenamenam model gabungan yang telah dinyatakan sebelum ini dipaparkan dalam Jadual 3. Keputusan menunjukkan bahawa model CCR dan BCC telah menghasilkan bilangan DMU cekap yang ramai. Keputusan ini adalah selari dengan keputusan yang diperoleh dalam kajian yang telah dibuat oleh Doyle dan Green (1994) dan Sarkis (2000) yang turut mendapat sejumlah besar DMU cekap apabila model CCR dan BCC digunakan. Walau bagaimanapun, Model Bi-O MCDEA-BCC yang dibina dalam kajian ini telah mengatasi model DEA yang lain khususnya model asalnya iaitu Model Bi-O MCDEA-CCR dalam mengukur kecekapan setiap DMU. Model ini telah memperoleh 5 buah DMU sebagai cekap berbanding 6 yang disarankan oleh model asalnya. Di samping itu, setiap model gabungan telah mencadangkan DMU paling cekap yang berbeza-beza iaitu DMU5, DMU35, DMU52, DMU54 dan DMU117.

Jadual 4 menunjukkan perbandingan yang dibuat terhadap kelima-lima DMU paling cekap berdasarkan keputusan model gabungan dengan keputusan simulasi DMU1 yang merupakan DMU semasa. Aspek pertama yang diambil kira untuk dibuat perbandingan adalah masa menunggu pesakit bagi mendapatkan rawatan. Berdasarkan keputusan simulasi yang diperoleh terhadap DMU tercekap ini, kelima-lima DMU tersebut telah berjaya menurunkan purata masa menunggu yang tinggi di Zon Hijau ini. Walau bagaimanapun, DMU5 dan DMU35 menunjukkan penurunan masa menunggu yang kecil berbanding dengan DMU52, DMU54 dan DMU117. DMU5 dan DMU35 didapati hanya menurunkan purata masa menunggu di Zon Hijau sekitar 121 min sahaja. Saranan untuk mengekalkan Jadual Kerja Doktor Zon Hijau yang asal oleh DMU ini dilihat menjadi penyebab kepada berlakunya penurunan masa menunggu yang kecil ini. Justeru, dapatlah disimpulkan bahawa jadual kerja yang diguna pakai pada ketika ini adalah tidak releven dan memerlukan penambahbaikan segera.

Penurunan purata masa menunggu di Zon Hijau yang lebih ketara dapat dilihat berlaku dalam DMU52, DMU54 dan DMU117. DMU52 telah mencatatkan penurunan masa menunggu di Zon Hijau kepada 63.4 minit berbanding 129.7 minit yang direkodkan dalam sistem sekarang. Selain itu, DMU54 dan DMU117 juga menunjukkan penurunan ketara dengan masing-masing menganggarkan para pesakit hanya menunggu sekitar 66.0 min bagi DMU54 dan 54.3 min bagi DMU117 bagi mendapatkan rawatan. Penurunan purata masa menunggu dalam kalangan Pesakit Zon Hijau ini berpunca daripada penyusunan kembali jadual kerja doktor di zon ini. Penambahbaikan yang dicadangkan oleh DMU ini iaitu mencadangkan jadual kerja yang baharu yang lebih bersesuaian dan menempatkan bilangan doktor yang munasabah khususnya pada waktu puncak telah menyebabkan proses rawatan berjalan dengan cepat dan lancar. Penjadualan kerja kakitangan yang baik dan teratur ini dapat meningkatkan prestasi kerja kakitangan (Aiken et al. 2002) dan mendorong mengurangkan berlakunya masalah lain seperti kesesakan, masa menunggu tinggi dan ketidakpuasan pesakit terhadap perkhidmatan hospital (Azaiez \& Al-Sharif 2005; Carter \& Lapierre 2001; Jeenanunta et al. 2013).

Jadual 4 turut menunjukkan penurunan masa menunggu pesakit Zon Hijau bagi mendapatkan rawatan ulangan selepas menjalani ujian tambahan. Penurunan purata masa menunggu melebihi $50 \%$ telah dicatatkan

JADUAL 3. Keputusan keenam-enam model gabungan

\begin{tabular}{clcc}
\hline No. & Model Gabungan & Bilangan DMU cekap & DMU paling cekap \\
\hline 1. & Model CCR Berorientasi Input \& Set Rujukan & 100 & DMU5 \& DMU54 \\
2. & Model BCC Berorientasi Input \& Set Rujukan & 104 & DMU35 \\
3. & Model CCR Berorientasi Input \& Kecekapan-Super & 100 & DMU117 \\
4. & Model BCC Berorientasi Input \& Kecekapan-Super & 104 & DMU117 \\
5. & Model Bi-Objektif MCDEA-CCR \& Kecekapan Silang & 6 & DMU52 \\
6. & Model Bi-Objektif MCDEA BCC \& Kecekapan Silang & 5 & DMU52 \\
\hline
\end{tabular}


JADUAL 4. Perbandingan antara DMU semasa (DMU 1) dan 5 DMU paling cekap

\begin{tabular}{lcccccc}
\hline \multicolumn{1}{c}{ DMU } & DMU 1 & DMU 5 & DMU 35 & DMU 52 & DMU 54 & DMU 117 \\
& & & & & & \\
Item & & & & & & \\
\hline Bilangan katil & 17 & 17 & 19 & 17 & 17 & 18 \\
Bilangan doktor & 12 & 13 & 13 & 12 & 11 & 13 \\
Bilangan jururawat & 12 & 11 & 11 & 11 & 12 & 13 \\
Purata tempoh masa menunggu (Min): & & & & & & \\
- Zon Hijau & 129.7 & 121.8 & 121.2 & 63.4 & 66.0 & 54.3 \\
- Rawatan ulangan (Zon Hijau) & 137.2 & 123.6 & 126.3 & 63.3 & 65.3 & 48.3 \\
Purata penggunaan tenaga kerja (\%): & & & & & & \\
- Katil & 65.9 & 66.9 & 67.3 & 69.1 & 65.7 & 68.4 \\
- Doktor Zon Merah & 89.3 & 83.0 & 84.1 & 80.0 & 79.5 & 85.3 \\
- Doktor Zon Kuning & 41.3 & 27.7 & 31.9 & 42.0 & 47.3 & 49.4 \\
- Doktor Zon Hijau & 98.2 & 98.3 & 98.3 & 94.2 & 94.1 & 90.0 \\
- Jururawat Zon Merah & 17.9 & 20.6 & 21.7 & 32.2 & 19.0 & 17.1 \\
- Jururawat Zon Kuning & 90.6 & 90.0 & 90.7 & 89.6 & 88.4 & 90.0 \\
\hline
\end{tabular}

oleh DMU52, DMU54 dan DMU117. Penurunan ini dapat dikaitkan dengan kesan daripada penambahbaikan yang telah berlaku pada proses sebelum ini iaitu menunggu untuk berjumpa kali pertama dengan Doktor Zon Hijau. Kajian telah menunjukkan bahawa proses yang terdapat dalam Sistem Jabatan Kecemasan adalah berkait antara satu sama lain. Sebarang perubahan yang dilakukan ke atas mana-mana proses dalam jabatan ini akan memberi kesan ke atas proses rawatan seterusnya (Aboukanda \& Latif 2013; Horwitz et al. 2010). Hal ini menunjukkan bahawa apabila masa menerima rawatan oleh doktor dapat dipertingkatkan, maka semakin cepat proses rawatan seterusnya akan berlangsung. Justeru, situasi ini dapat mengurangkan tempoh keseluruhan masa rawatan dan pesakit tersebut dapat dibenarkan pulang ke rumah awal selepas menerima rawatan.

Dalam menambah baik masalah penggunaan tenaga kerja sumber pula, hanya DMU52 yang berjaya memenuhi kesemua kehendak kajian. DMU52 telah meningkatkan peratusan rendah kepenggunaan katil, Doktor Zon Kuning dan Jururawat Zon Merah. Contohnya, $17.9 \%$ purata penggunaan tenaga kerja Jururawat Zon Merah dalam sistem sekarang telah ditingkatkan kepada $32.2 \%$ setelah bilangan sumber tersebut dikurangkan kepada 4 orang. Peningkatan peratusan penggunaan tenaga kerja sumber ini menunjukkan ia digunakan secara lebih baik. Penggunaan sumber secara lebih optimum ini dapat mengelakkan daripada berlakunya lebihan pekerja yang dapat merugikan kewangan jabatan.

Di samping itu, peratusan penggunaan yang tinggi Doktor Zon Merah dan Zon Hijau serta Jururawat Zon Kuning turut dapat dikurangkan dengan baik. Menerusi DMU52, 89.3\% penggunaan tenaga kerja Doktor Zon Merah telah berkurangan kepada $80 \%$ manakala $98.2 \%$ purata penggunaan tenaga kerja Doktor Zon Hijau telah berjaya dikurangkan kepada 94.2\% . Bagi Jururawat Zon Kuning pula, DMU52 telah memberikan bacaan purata penggunaan tenaga kerja sumber iaitu sebanyak $89.6 \%$ berbanding
90.6\% dalam sistem semasa. Justeru, apabila penggunaan tenaga kerja ini dapat dikurangkan kepada peratusan yang lebih rendah dan munasabah, masalah tekanan di tempat kerja dapat diatasi dan juga penurunan moral pekerja berkenaan turut dapat dikawal dengan baik. Hal ini sekali gus dapat mengelakkan daripada berlakunya kecuaian dalam melakukan prosedur rawatan (Ansari et al. 2015).

Sementara itu, DMU5, DMU35, DMU54 dan DMU117 didapati hanya berjaya menambahbaik sebahagian peratusan penggunaan tenaga kerja sumber. DMU5 dan DMU35 gagal menambahbaik penggunaan tenaga kerja Doktor Zon Kuning dan Zon Hijau bahkan telah menurunkan lagi peratusan pengunaan tenaga kerja Doktor Zon Kuning kepada $27.7 \%$ dan 31.9\%. Cadangan penambahan seorang Doktor Zon Kuning yang baharu oleh kedua-dua DMU ini dipercayai telah menyebabkan berlakunya pengurangan peratusan penggunaan tenaga kerja ini. Hal ini mengakibatkan berlakunya lebihan sumber dalam kalangan Doktor Zon Kuning. Lebihan sumber ini akan merugikan pihak pengurusan yang terpaksa berbelanja lebih demi mengambil kakitangan yang baharu sedangkan sumber-sumber ini tidak digunakan secara optimum (Holm et al. 2013).

Pengoptimuman sumber yang dicadangkan oleh DMU54 dan DMU117 pula telah menyebabkan tiada perubatan dilakukan ke atas beberapa sumber jabatan. Walaupun tidak dinafikan peratusan perubahan penggunaan tenaga kerja yang diberikan oleh DMU117 dilihat agak besar pada sesetengah sumber berbanding DMU-DMU lain, namun perkara ini hanya tercapai dengan melakukan perubahan yang besar terhadap keseluruhan sistem. DMU117 mencadangkan untuk menambahbaik sistem ini dengan menambah bilangan kakitangan baharu pada kebanyakan zon rawatan. Perubahan besar ini akan menyebabkan pihak pengurusan perlu memperuntukkan sejumlah peruntukan kewangan yang besar seandainya DMU ini dipilih untuk mempertingkatkan tahap kecekapan operasi jabatan ini. 
Berdasarkan perbandingan ini, dapat disimpulkan bahawa DMU52 merupakan DMU terbaik untuk dipilih bagi meyelesaikan kesesakan yang berlaku di Jabatan Kecemasan PPUKM. DMU52 telah berjaya mematuhi kedua-dua kriteria wajib bagi menjadikan sebuah jabatan kecemasan lebih cekap iaitu masa menunggu rendah dan penggunaan tenaga kerja sumber yang munasabah seperti yang telah disarankan oleh Jun et al. (2013) dan Weng et al. (2011). DMU52 telah menyebabkan masa menunggu di Zon Hijau bagi mendapatkan rawatan kali pertama dan kedua turun kepada 63 minit. Selain itu, DMU52 turut membaiki kesemua pengunaan tenaga kerja sumber yang kurang memuaskan dengan lebih baik.

Sementara itu, DMU52 juga layak dipilih kerana melaluinya tiada sebarang perubahan besar dan penambahan bilangan sumber yang baharu perlu dilakukan. DMU ini hanya menyusun atur kembali kedudukan sumber yang sedia ada dalam jabatan ini bagi menjadikan konfigurasi sumbernya optimum. Jadual 5 menunjukkan konfigurasi sumber yang disarankan oleh DMU52 iaitu terdapat dua orang Doktor Zon Merah pada setiap syif kerja pagi dan petang, manakala hanya seorang Doktor Zon Merah pada syif kerja malam. Bagi Doktor Zon Kuning pula, terdapat 2 orang doktor bertugas pada setiap syif manakala Doktor Zon Hijau menggunakan Jadual Kerja Doktor Zon Hijau 2 (S2) iaitu seramai 8 doktor (tiga doktor pada syif 0700 - 1400, tiga doktor pada syif 1400 - 2100 dan dua doktor pada syif 2100 - 0700). Penambahbaikan yang dilakukan dalam jadual ini adalah dengan menukarkan masa bekerja doktor agar sama dengan syif kakitangan lain dan menempatkan lebih ramai doktor bertugas pada waktu puncak. Waktu puncak di Jabatan Kecemasan PPUKM adalah pada jam 12:00 tengah hari hingga ke 2:00 petang dengan peningkatan jumlah pesakit bermula dari jam 7:00 pagi (Aminuddin et al. 2016). Sementara itu, bilangan jururawat di Zon Merah dalam ketiga-tiga syif kerja adalah sama iaitu 4 orang. Di Zon Kuning, 6 orang jururawat bekerja pada syif kerja pagi dan petang manakala hanya 4 orang jururawat bekerja pada syif malam. Jumlah keseluruhan bilangan katil rawatan pula adalah sebanyak 17 buah.

Berdasarkan Jadual 5, penambahan doktor di Zon Merah yang disarankan oleh DMU ini dapat dilaksanakan dengan hanya menempatkan seorang doktor yang tidak lagi ditempatkan di Zon Hijau untuk bertugas di Zon Merah. Dengan berbuat demikian, situasi ini dapat membantu mengurangkan kos yang perlu ditanggung oleh pihak hospital dalam proses untuk meningkatkan tahap kecekapan Jabatan Kecemasan PPUKM. Kos tersebut bolehlah diperuntukkan untuk membiayai urusan pembangunan lain seperti membeli peralatan rawatan dan ubatan yang lebih moden seperti membesarkan kapasiti Jabatan Kecemasan. Kos yang minimum ini juga dapat menjimatkan kewangan negara yang sedang berdepan dengan masalah kegawatan ekonomi pada ketika ini.

Selain menjimatkan kos, cadangan yang terdapat dalam DMU52 ini turut selari dengan saranan kerajaan seperti yang terkandung dalam Rancangan Malaysia ke-11. Rancangan ini telah memberi penekanan untuk membaiki kecekapan perkhidmatan Jabatan Kecemasan di hospitalhospital kerajaan dengan menyusun semula proses dan prosedur kerja di hospital, mengoptimumkan penggunaan sumber sedia ada serta mengamalkan amalan kerja yang terbaik ketika memberikan rawatan kepada pesakit (Unit Perancang Ekonomi 2016). Melalui pelaksanaan strategi ini, diharap sumber sedia ada dapat dimanfaatkan sepenuhnya dengan optimum, masa menunggu pesakit semakin singkat dan masyarakat semakin berpuas hati terhadap khidmat rawatan kesihatan yang disediakan. Justeru, secara tidak langsung perkara ini dapat membantu pihak kerajaan merealisasikan Wawasan 2020 negara yang cenderung menjadikan Malaysia sebuah negara berpendapatan tinggi serta mempunyai piawai dan kualiti hidup yang baik.

\section{KESIMPULAN}

Dalam kajian ini, sebuah model simulasi Jabatan Kecemasan PPUKM telah dibangunkan untuk memberikan gambaran yang jelas akan suasana yang berlaku dalam Jabatan Kecemasan PPUKM serta dapat menunjukkan cara tingkah laku pesakit dan sumber jabatan berkenaan. Model simulasi ini juga digunakan untuk menguji sejauh mana keberkesanan penambahbaikan yang dilakukan ke atas sistem tanpa mengganggu sistem asal jabatan.

Pemboleh ubah yang digunakan dalam kajian ini adalah Jururawat Triage Sekunder, Doktor Zon Kuning, Doktor Zon Hijau dan Katil Zon Merah. Kelebihan penggunaan pemboleh ubah yang lebih spesifik ini akan menghasilkan keputusan kajian yang lebih khusus dan releven. Keputusan yang dihasilkan ini mampu memberikan gambaran yang lebih tepat dan jelas akan situasi yang berlaku dalam sistem yang dikaji. Berbeza dengan kajian lepas, pemboleh ubah yang digunakan adalah berbentuk umum contohnya doktor, jururawat dan katil yang memberikan dapatan yang lebih umum dan nilai bacaan dapatan secara purata. Ini boleh mengakibatkan keadaan sebenar sistem ditafsirkan secara tidak tepat.

Hasil penemuan dalam kajian ini juga jelas telah membuktikan DMU52 yang diperoleh menerusi penggunaan

JADUAL 5. Alternatif penambahbaikan/DMU52

\begin{tabular}{ccccccc}
\hline DMU & $\begin{array}{c}\text { Doktor Zon } \\
\text { Merah }\end{array}$ & $\begin{array}{c}\text { Doktor Zon } \\
\text { Kuning }\end{array}$ & $\begin{array}{c}\text { Doktor Zon } \\
\text { Hijau }\end{array}$ & $\begin{array}{c}\text { Jururawat Zon } \\
\text { Merah }\end{array}$ & $\begin{array}{c}\text { Jururawat Zon } \\
\text { Kuning }\end{array}$ & Katil \\
\hline 52 & $(2,2,1)$ & $(2,2,2)$ & S2 & $(4,4,4)$ & $(6,6,4)$ & 17 \\
\hline
\end{tabular}


kaedah simulasi beserta gabungan Model Bi-O MCDEA-BCC dengan Kecekapan Silang merupakan DMU paling cekap dan terbaik untuk dipilih bagi menyelesaikan kesesakan yang berlaku di Jabatan Kecemasan PPUKM. Pengurusan sumber yang dicadangkan dapat menambah satu Doktor Zon Merah yang diambil daripada pengurangan seorang Doktor Zon Hijau dan bilangan jururawat Zon Merah juga dapat dikurangkan.

\section{PENGHARGAAN}

Jutaan terima kasih diucapkan kepada Jabatan Kecemasan Pusat Perubatan Universiti Kebangsaan Malaysia (PPUKM) atas perkongsian data. Kajian ini telah dijalankan menggunakan geran penyelidikan FF-2015-246.

\section{RUJUKAN}

Aboukanda, E. \& Latif, M. 2013. Exploiting simulation to reduce patient waiting time using a streaming strategy in an emergency department. International Journal of Advanced Technology \& Engineering Research 3(2): 79-86.

Aiken, H.L., Charles, S.P., Sloane, D.M., Sochalski, J. \& Silber, S.H. 2002. Hospital nurse staffing and patient mortality, nurse burnout and job dissatisfaction. JAMA 288(16): 1987-1993.

Al-Refaie, A., Fouad, R.H.,Li, M.\& Shurrab, M. 2014. Applying simulation and DEA to improve performance of emergency department in a Jordanian hospital. Simulation Modelling Practice and Theory 41: 59-72.

Aminuddin, W.M.W.M., Ismail, W.R., Harunarashid, H., Ali, R.A., Ismail, M.S. \& Johar, M. 2016. Utilization of Emergency Department, UKM Medical Centre: Pattern of patient. Jurnal Teknologi 4: 53-58.

Andersen, P. \& Petersen, N. 1993. A procedure for ranking efficient units in data envelopment analysis. Management Science 39(10): 1261-1264.

Ansari,Z.M., Yasin, H.,Zehra, N. \& Faisal,A. 2015. Occupational stress among Emergency Department (ED) staff and the need for invesment in health care; A view from Pakistan. British Journal of Medicine \& Medical Research 10(10): 1-9.

Azadeh, A., Sepahi, M. \& Haghighi, S.M. 2013. An integrated simulation-DEA approach to improve quality care of medical centres. Int. J. Process Management and Benchmarking 3(3): 352-370.

Azaiez, M.N. \& Al-Sharif, S. 2005. A 0-1 goal programming model for nurse scheduling. Computers \& Operations Research 32(3): 491-507.

Azlan, N., Saibon, I.M. \& Azizol, M. 2013. Management of emergency department overcrowding (EDOC) in a teaching hospital. Med.\& Health 8(1): 42-46.

Bal, H. \& Orkc, H.H. 2010. Improving the discrimination power and weights dispersion in the data envelopment analysis. Computers \& Operations Research 37(1): 99-107.

Banker, R., Charnes, A. \& Cooper, W. 1984. Some models for estimating technical and scale inefficiencies in data envelopment analysis. Management Science 30(9): 10781092

Brailsford, S.C. 2007. Tutorial: Advances and challenges in healthcare simulation modeling. Proceeding of the 2007 Winter Simulation Conference. pp. 1436-1448.

Carmen, R., Defraeye, M. \& Van Nieuwenhuyse, I. 2015. A decision support system for capacity planning in emergency departments. Int. J. Simul. Model 14(2): 299-312.
Carrilloa, M. \& Jorge, J.M. 2015. A multiobjective DEA approach to ranking alternatives. Expert Systems With Applications 12: 1-27.

Carson, J.S. 2002. Model verification and validation. Proceeding of the 2002 Winter Simulation Conference. pp. 52-58.

Carter, M.W. \& Lapierre, S.D. 2001. Scheduling emergency room physicians. Health Care Management Science 4(4): 347-360.

Centeno, M.A., Giachetti, R., Linn, R. \& Ismail, A.M. 2003. A simulation-ILP based tool for scheduling ER staff. Proceeding of the 2003 Winter Simulation Conference. pp. 1930-1938.

Charnes, A., Cooper, W. \& Rhodes, E. 1978. Measuring the efficiency of decision making units. European Journal of Operational Research 2(6): 429-444.

Cooper, W., Seiford, L. \& Tone, K. 2007. Data Envelopment Analysis. New York: Springer.

Cowan, R.M. \& Trzeciak, S. 2005. Clinical review: Emergency department overcrowding and the potential impact on the critically ill. Critical Care 9(3): 291-295.

Di, S., Lorenzo, S., Vaughan, L., Lalle, I., Magrini, L. \& Magnanti, M. 2015. Overcrowding in emergency department: An international issue. Intern Emerg. Med. 10(2): 171-175.

Doyle, J. \& Green, R. 1994. Efficiency and cross-efficiency in DEA: Derivations, meanings and uses. Journal of the Operational Research Society 45(5): 567-578.

Emrouznejad, A. 2012. Data Envelopment Analysis Homepage. http://www.DEAzone.com.

Eskandari, H., Riyahifard, M., Khosravi, S. \& Geiger, C.D. 2011 Improving the emergency department performance using simulation and MCDM methods. Proceeding of 2011 Winter Simulation Conference.pp. 1211-1222.

Francisco, A., Augusto, F., Marins, S., Tamura, P.M. \& Dias, E.X. 2017. Bi-Objective multiple criteria data envelopment analysis combined with the overall equipment effectiveness: An application in an automotive company. Journal of Cleaner Production 157: 278-288.

Gharahighehi, A., Kheirkhah, A.S., Bagheri, A. \& Rashidi, E. 2016. Improving performances of the emergency department using discrete event simulation, DEA and the MADM methods. Digital Health 2: 1-14.

Ghasemi, M., Ignatius, J. \& Emrouznejad, A. 2014. A bi-objective weighted model for improving the discrimination power in MCDEA. European Journal of Operational Research 233(3): 640-650

Holm, L.B., Luras, H. \& Dahl, F.A. 2013. Improving hospital bed utilisation through simulation and optimisation. International Journal of Medical Informatics 82(2): 80-89.

Horwitz, L.I., Green, J. \& Bradley, E.H. 2010. US emergency department performance on wait time and length of visit. Annals Of Emergency Medicine 55(2): 133-141.

Jeenanunta, C., Ayudhya, S.I.N., Doungraksa, P., Sereewattanapong, C., Pongtanupattana, A. \& Nuchjarin Intalar. 2013. Resource analysis in emergency department using simulation-based framework. 4th International Conference on Engineering Project and Production Management. pp. 1073-1083.

Jun, J., Jacobson, S. \& Swisher, J. 2013. Application of discreteevent simulation in health care clinics: A survey. Journal of the Operational Research Society 50(2): 109-123.

Kelton, W.D., Sadowski, R.P. \& Swets, N.B. 2010. Simulation with Arena. New York: McGraw-Hill.

Li, X. \& Reeves, G.R. 1999. A multiple criteria approach to data envelopment analysis. Engineering and Technology Management 115: 507-517. 
Lv, X., Li, L., Xu, W. \& Rong, X. 2015. Sufficient and comprehensive measurement of multi-band camouflage screen performance applying bi-objective super-efficiency dea. The 10th International Conference on Computer Science \& Education. pp. 542-546.

Medical Development Division. 2012. Emergency Medicine and Trauma Services Policy. http://www.moh.gov.my/index.php/ pages/view/195. Diakses pada 5 Disember 2015.

Moashiri, H., Aljunid, S.M., Amin, R.M., Dahlui, M. \& Ibrahim, W.N. 2011. Measuring efficiency of teaching hospital in Malaysia. International Journal of Business and Management 6(4): 207-213.

Meza, L.A. \& Lins, M.P.E. 2002. Review of methods for increasing discrimination in data envelopment analysis. Annals of Operations Research 116(1-4): 225-242.

Paul, S.A., Reddy, M.C. \& Deflitch, C.J. 2010. A systematic review of simulation studies investigating emergency department overcrowding. Simulation 86(8-9): 559-571.

Redeker, G.A., Webber, T., Czekster, R.M., Quickert, S. \& Bowles, J.K.F. 2017. Estimating capacity and resource allocation in healthcare settings using business process modelling and simulation. Anais XXXVII Congresso da Sociedade Brasileira de Computação. pp. 5-8.

Ruohonen, T., Neittaanmaki, P. \& Teittinen, J. 2006. Simulation model for improving the operation of the emergency department of special health care. The Proceeding of 2006 Winter Simulation Conference. pp. 453-458.

Sarkis, J. 2000. Comparative analysis of DEA as a discrete alternative multicriteria decision tool. European Journal of Operational Research 123(3): 543-557.

Sexton, T. 1986. Measuring Efficiency: An Assessment of Data Envelopment Analysis. San Francisco: Jossey-Bass.

Somma, S.D., Paladino, L., Vaughan, L., Lalle, I., Magrini, L. \& Magnanti, M.2015. Overcrowding in emergency department: An international issue. Intern. Emerg. Med. 10(2): 171-175.

Subramaniam, S. 2016. Kementerian Kesihatan Usaha Tangani Pengurangan Bajet. https://www.bharian.com.my/ node/181872. Diakses oleh 10 Ogos 2016.
Tahar, R.M. 2006. A Practical Approach to Computer Simulation Modelling. Serdang: Universiti Putra Malaysia Press.

Unit Perancang Ekonomi. 2016. Rancangan Malaysia Ke-Sebelas 2016-2020.

Uriarte, A.G., Zuniga, E.R., Moris, M.U. \& Ng, A.H.C. 2015. System design and improvement of an emergency department using simulation-based multi-objective optimization.Journal of Physics 1: 1-11.

Weng, S., Tsai, B.S., Wang, L.M. \& Chang, C.Y. 2011. Using simulation and data envelopment analysis in optimal healthcare efficiency allocations. The Proceeding of 2011 Winter Simulation Conference. pp. 1295-1305.

Yarmohammadian, M.H., Rezaei, F., Haghshenas, A. \& Tavakoli, N. 2017. Overcrowding in emergency departments: A review of strategies to decrease future challenges. Journal of Research in Medical Sciences 22(1): 23.

Zeinali, F., Mahootch, M. \& Sepehri, M.M. 2015. Resource planning in the emergency departments: A simulation-based metamodeling approach. Simulation Modelling Practice and Theory 53: 123-138.

Pusat Pengajian Sains Matematik

Fakulti Sains dan Teknologi

Universiti Kebangsaan Malaysia

43600 UKM Bangi, Selangor Darul Ehsan

Malaysia

*Pengarang untuk surat-menyurat: email: wrismail@ukm.edu.my

Diserahkan: 20 September 2017

Diterima: 5 Mei 2018 